\title{
A Comparative Study of Attitude towards Grading System of Teachers of Senior Secondary Schools in Rural and Urban areas of North-East Delhi
}

\author{
Ms. Kavita
}

Assistant Professor, Guru Nanak College of Education, Punjabi Bagh, New Delhi, India

\begin{abstract}
Evaluation of students about the success and failure of education shows, therefore, the better the evaluation system, the better the education and the shortcomings of education are found. The grading system is an evaluation system in which students do not score, But to know about its effectiveness, it is important to know the views of teachers, because one The evaluation system is not the same for all the students. The teachers know more about the best of the students.
\end{abstract}

Keywords : Evaluation and Grading System

\section{INTRODUCTION}

Education is a natural process that runs from birth to death. Education is the basis of man's physical, mental, social and secondary powers. By this he becomes a responsible citizen of the society and contributes to the development of society.

Generally, the word education is used in the English language for Education, its origins are composed by the Latin word 'education' which means - Teaching. This word is made up of E + DOO. E means - from inside, the word duko means - to develop from within. It means that by education, the person is educated and internal powers are developed.

\section{Education has two dimensions -}

1- Compressed

2- Comprehensive

According to Frobel, "Education is a process by which the internal forces of the child are brought out."
According to Gandhiji, "I mean by education that is the process of development of all forms of the body, mind and soul of the child and man."

According to Socrates, "The meaning of education is to bring the universal views of the present world into the invisible form of the human brain."

According to John Lock, "Plants are grown by agriculture and by human education."According to John DV, "Education is the development of all the qualifications of a person by which he develops the ability to control the atmosphere and fulfill its potential."

Whenever we start doing any work, there is no purpose hidden behind it. After working for some time we need to know that what we are trying to do is going on in the right direction and in what kind of support we are getting in achieving our objectives. In this way, evaluating the meaning of efforts in achieving objectives is evaluated. Thus evaluation gives us the opportunity to evaluate the value of our efforts and efforts to fulfill our power.

The field of evaluation is quite extensive as it seeks to evaluate this value of all the parties and traders involved in the learning process, in which all aspects 
emerge from power. Inherent vulnerabilities have emerged so that their right solutions make teaching learning so effective. It is possible that for the welfare of the students, the achievement of the specified learning objectives is simple, sustainable and effective areas to be done.

Different educationist has defined evaluation as following :

Evaluation is the assignment of symbol to phenomenon in order to characterize the worth or value of a Phenomenon, usually with reference to some cultural or scientific standards. - James M.

\section{Bradfield}

The term evaluation is closely related to measurement. It is in some respect, inclusive including informal and intuitive judgment of pupil's progress. Evaluation is describing something in of selected attributes and judging the degree of acceptability or suitability of that which has been described.

\section{-Thorndike and Hegan}

Evaluation is a systematic process of collecting analyzing and interpreting information to determine the extent to which pupil's are achievement instructional objectives.

\section{-Norman E.Gronlund and Robert L.Linn}

The process of ascertaining or judging the value or amount of something by use of a standard of appraisal includes judgment of pupil's progress. Evaluation is describing something in term of internal evidence and external criteria.

\section{-CV GOOD}

By the above definition we can know that the area of assessment is very broad. The process of continuity and continuity is found in this process. The two characteristics of evaluation are continuity and continuity as follows.

(A) Prevalence of Evaluation. The generality of the evaluation is expressed as follows: -

- The area of assessment is wide.

- evaluation in teaching

- The method used in evaluation is comprehensive: -

(A) - The resultant technique

- Functional and experimental tests and examinations-

- Written tests and exams

(B) Qualitative techniques-

Inspection and observation method-

Question and Check list

\section{A brief history of grading system for evaluation: -}

First of all, keith Huskin talked about its grading system. The first grading system came in Cambridge University of England, 1792. Come on the basis of technology. Evaluation on the basis of technology, this basic sector of education is effective for both academic theory and experimentation. All grades in England are assessed by the grading system.

\section{Grading System: -}

The most emphasis has been given on the evaluation of students in improving the examination system of India but recently the grading system has been added to the evaluation system for the prevailing higher secondary students. It has been taken care of for evaluation of the examination system that can evaluate the development of the student with the valid and credible wealth and empower the learning process i.e. it should be resolved of the coincidence and the work should be emphasized on the continuous and detailed Evaluation should improve the conduct of the examination, changes in teaching methods, and grading should be used instead of inference. 
Many times the actual score is different from the original score. It is very difficult to differentiate between 59 and 60 marks and 32 and 33 marks. Thus there is an impact on the achievement of the student in one or two numbers in the number. Many times the teacher's attitude is different for checking examination copy, so the grading system has proven successful.

The Higher Education Ratio Commission (1996-77) gave the representation of the grade-grade system.

\begin{tabular}{|l|l|l|}
\hline General Level & Points & $\begin{array}{l}\text { Marks Obtained } \\
\text { in Percentage }\end{array}$ \\
\hline O & 6 & $75 \%$ and Above \\
\hline A & 5 & $65-74$ \\
\hline B & 4 & $55-64$ \\
\hline C & 3 & $45-54$ \\
\hline D & 2 & $35-44$ \\
\hline E & 1 & $25-34$ \\
\hline F & 0 & $0-24$ \\
\hline
\end{tabular}

Although different types of grading have been proposed, but are generally as broad as 5 points, 9 points and many measurements. The more diffusion power required in examining the examiner's answer sheets and providing more reliable points. Although two candidates get one point in any examination or both get zero marks, the scores earned by the two students will be similar in accordance with the marks, but they will not be equal in the psychological terms. A student who has never studied, zero marks can be real, but if the person studied for the whole year but could not pass the exam due to some reason, the number of such students can not be counted according to his achievement.

Thus, the level of achievement of the two students can be different even if the number of two students is equal.

\section{Need of the Study}

Each teacher has its own opinion about the evaluation under the examination system, that is, there is a different perspective on evaluation of rural and urban teachers, because it is not necessary that the same assessment system is effective for urban students and that is for rural students, it is also as effective.

Comparative votes according to the areas of the teachers about the grading system can be understood from how important this grading system is for evaluation and how efficient the grading system is based on the areas. Teachers of different areas get different views for any exam system, through which this study can easily be used to find out that the grading system is positive and positive for students of rural and urban areas.?

It is most important to know the opinion of teachers about any new education system as it is a teacher who can properly understand the mindset, thoughts and momentum of the students whose direct impact falls on the students' academic achievement.

Today, the students studying in the urban areas are competing for one another ahead of the competition. If one student receives two marks more than the other student, the second student is motivated to complete the two marks. In the same village students, such a trend is seen. It is easy to know from the opinion of the teachers that how the impact of grading system on students is being applied to their motivation and educational achievement.

Grading system for students from 2010 to 10th standard under higher secondary education was introduced in which students were given grades instead of numbers, so it is not necessary that 
teachers in all areas in Delhi are fully agreed with this system, hence the rural and it is necessary to know comparative approaches to urban areas grading system. It is very important for students to evaluate not just the knowledge but to evaluate the overall development of the lawful and credible.

\section{Statement of the Problem}

A Comparative Study of Attitude towards Grading System of Teachers of Senior Secondary schools in rural and urban areas of North-East Delhi.

\section{Purpose of study}

- TO study the attitude of teachers towards the grading system

- To study Compare of the approach of male teachers and Female teachers.

- To study Understanding the attitude of urban teachers and rural teachers about grading system

- To study suggestions for improvement of the evaluation system.

\section{Hypothesis of the study}

- There will be no difference in the approach towards grading system of rural and urban women teachers

- There will be no difference in attitude towards rural and urban male teachers' grading system.

- There will be no difference in approach towards grading system of rural male teachers and urban teachers.

- There will be no difference in approach towards grading system of rural male teachers and urban teachers.

\section{METHOD AND PROCEDURE OF STUDY}

\section{Population:-}

In this study, the urban and rural high schools of East Delhi area have been included.

\section{Sample :-}

The researcher has taken only the high schools of East Delhi for her research. Only 8 schools in entire schools have been taken in which 4 schools have been included in rural area and 4 schools from urban areas.

\section{Method}

The researcher has adopted the survey method and factual method in this research to solve its problem.

\section{Process :-}

In this research, self-made questionnaire attempts have been made by the researcher.

\section{Delimitations}

In the research work, 100 teachers of the upper secondary schools of East Delhi have been included.

-50 teachers have been taken from the rural area and 50 to the urban area school.

- 25 female teachers have been included in the urban area and 25 women's teachers from rural areas.

-25 male teachers are included in urban areas and 25 male teachers from rural areas.

\section{Result Analysis}

\begin{tabular}{|l|l|l|l|l|l|}
\hline Category & total & mean & S.D & $\begin{array}{l}\text { Value } \\
\text { of } \mathrm{t}\end{array}$ & $\begin{array}{l}\text { Table } \\
\text { value }\end{array}$ \\
\hline $\begin{array}{l}\text { Rural } \\
\begin{array}{l}\text { Female } \\
\text { Teachers }\end{array}\end{array}$ & 25 & 15.52 & 1.60 & & \\
$\begin{array}{l}\text { Urban } \\
\text { female } \\
\text { Teachers }\end{array}$ & 25 & 17.04 & 1.48 & & \\
\hline
\end{tabular}

There was no difference in attitude towards rural and urban teachers' grading system. 


\begin{tabular}{|l|l|l|l|l|l|}
\hline Category & total & mean & S.D & $\begin{array}{l}\text { Value } \\
\text { of t }\end{array}$ & $\begin{array}{l}\text { Table } \\
\text { value }\end{array}$ \\
\hline $\begin{array}{l}\text { Rural Male } \\
\text { Teachers }\end{array}$ & 25 & 16 & 1.64 & 0.037 & 2.02 \\
$\begin{array}{l}\text { Urban } \\
\text { Male } \\
\text { Teachers }\end{array}$ & 25 & 17.48 & 1.17 & & \\
\hline
\end{tabular}

There was no difference in attitude towards rural and urban male teachers' grading system.

\begin{tabular}{|l|l|l|l|l|l|}
\hline Category & total & mean & S.D & $\begin{array}{l}\text { Value } \\
\text { of t }\end{array}$ & $\begin{array}{l}\text { Table } \\
\text { value }\end{array}$ \\
\hline $\begin{array}{l}\text { Rural Male } \\
\text { Teachers }\end{array}$ & 25 & 16 & 1.64 & & \\
$\begin{array}{l}\text { Urban } \\
\text { Female } \\
\text { Teachers }\end{array}$ & 25 & 17.04 & 1.48 & 4.94 & 2.02 \\
\hline
\end{tabular}

There was no special difference in the approach towards grading system of rural male teachers and urban female teachers.

\begin{tabular}{|l|l|l|l|l|l|}
\hline Category & total & mean & S.D & $\begin{array}{l}\text { Value } \\
\text { of t }\end{array}$ & $\begin{array}{l}\text { Table } \\
\text { value }\end{array}$ \\
\hline $\begin{array}{l}\text { Rural } \\
\begin{array}{l}\text { Female } \\
\text { Teachers }\end{array}\end{array}$ & 25 & 15.52 & 1.60 & & \\
$\begin{array}{l}\text { Urban Male } \\
\text { Teachers }\end{array}$ & 25 & 17.04 & 1.48 & 3.494 & 2.02 \\
\hline
\end{tabular}

There was no special difference in the approach towards grading system of rural female teachers and urban male teachers.

\section{Findings}

Teachers were not fully convinced to implement grading system for secondary education. In rural areas teachers and teachers of urban areas have found a difference in the approach for grading system.

\section{CONCLUSION}

According to most teachers, the grading system will not have a competitive spirit in the students but all the teachers are unable to agree to the grading system. In this way it can be said that the Education Committee should focus both its positive and negative effects before deciding the evaluation system. There is an important role of evaluation in the teaching learning process, which also affects students' academic achievement and motivation. The teacher's views must be taken for a good evaluation system.

\section{REFERENCES}

[1]. Educational Research : A Guide to the Process by Noemen E.Wallen, Jack R.Fraenkel

[2]. Kaul Lokesh, Process of educational Resrearch, Vikas publishing House

[3]. Verma Dr. Praveen, Education in modern India

[4]. Bhandari R.K. , Educational development of India, Education and cultural ministry, New Delhi(1983)

[5]. Walia Dr. J.S., Secondary Education and School Management, Ahempal Prakashak, Allahabad.

Website:

[6]. www.cbse.co.in

[7]. www.phychometrics.com

[8]. www.mns.com

[9]. www.edutophia.org

[10]. www.vidyapath.org

[11]. www.time.com/time/clasroom 
[12]. www.ehow.com/list-9935940-disadvantagesletter-gradingsystem.html

\section{Cite this article as :}

Kavita, "A Comparative Study of Attitude towards Grading System of Teachers of Senior Secondary Schools in Rural and Urban areas of North-East Delhi", International Journal of Scientific Research in Science and Technology (IJSRST), Online ISSN : 2395-602X, Print ISSN : 2395-6011, Volume 6 Issue 2, pp. 606-611, March-April 2019. Available at doi : https://doi.org/10.32628/IJSRST1962131

Journal URL : http://ijsrst.com/IJSRST1962131 